\title{
Cleaning Regime for Pinctada margaritifera (Linneaus, 1758) in Savusavu Bay, Fiji
}

Ram EJ* and Morris C

School of Marine Studies, University of the South Pacific, Suva, Republic of Fiji

\begin{abstract}
One of the main challenges of pearl industry in Fiji and the South Pacific is trying to control the harmful effects of excessive biofouling on Mother of Pearl Oysters until they are ready implanting and grafting process. Controlling and cleaning biofouling is a major expense of any pearl farm operation. Biofouling also has a significant effect on the growth rate and survival of pearl oysters. An experiment was setup in Valili pearl farm to find out the best cleaning regime for highest growth rate of Mother of Pearl oysters from January 2012 through to June 2012. The experimental setup had 4 treatments; 2 week, 4 week, 6 week and 20 week cleaning regime. Each treatment had 5 panel nets with 21 oysters. The results showed that the oysters treated with 4 and 6 week cleaning regime had significantly higher growth rates than 2 and 20 week cleaning regime.
\end{abstract}

Keywords: Pinctada margaritifera; Mother of pearl oysters; Cleaning regime; Growth rate

\section{Introduction}

The chapter discusses the impact of a cleaning regime on the growth of spats conducted at 2, 4, 6 and 20 weeks to determine whether there is a significant difference in growth and survival. New sets of spats were suspended in the Savusavu bay and subjected to different cleaning regimes. The culture material used was pocket panel nets.

A vital feature of pearl oyster culture is growth [1]. Growth is the increase in length or weight over a period of time. Fast growth of oysters is preferred in the pearling industry as it not only minimizes the harvest time but it also increases profit margins [1]. The faster the spats grow to a suitable size for seeding the faster the nuclei can be implanted for pearl formation [2]. Bigger pearls can be formed from larger oysters [3]. Bigger pearls are in demand nowadays [1].

The growth of pearl oysters is influenced by various factors. These factors can be exogenous which include, genetic potential and neurohormonal expression or endogenous which include the environment and culture conditions. Any of these factors can affect the physiological processes of the oysters' growth [4]. Salinity and temperature are key factors influencing oyster growth as studied by O'Connor and Lawler in the year 2003. A study indicated that Pinctada imbticata could survive in salinities ranging from 32-35 ppt [5]. In a separate study Pinctada maxima tolerated a salinity range of 25-45 ppt [6].

Temperature can affect the physiological rates of oysters [7]. High temperatures cause an increase in oxygen intake and ammonia excretion in Pinctada mazatlanica [8]. Decreased temperatures in the larval phase of bivalves can deactivate some enzymes and lead to mucus secretion in other types of oysters which can influence their growth rate $[9,10]$.

Another factor which influences the growth of oysters is depth. The concentration of available food and extent of fouling depends on depth [1]. A study on scallop indicated that plankton biomass and temperature decreased with increasing depth resulting in increased scallop mortalities [11]. Another study showed that there were no major differences in growth of Pteria penguin at $1 \mathrm{~m}, 4 \mathrm{~m}$, and $8 \mathrm{~m}$ depths but there was increased fouling at the surface which caused high mortality of this species of oyster [12].

\section{Research Methodology}

\section{Study site}

This study was conducted in Savusavu Bay, Vanua Levu, Fiji from January 2012 through to June 2012. The study was conducted using existing long lines of the pearl farm known as Valili Pearl Farms which culture P. margaritifera.

\section{Spat collection and selection}

Oyster spats used for this experiment were collected from Savusavu Bay using Accordion-style spat collectors. Spats with a size between 40 $\mathrm{mm}$ and $55 \mathrm{~mm}$ Dorsal Ventral Measurement (DVM) also known as Dorso-ventral Height (DVH) were selected for the experiment as these were the most abundant sizes available from the $20 \mathrm{~mm}$ to $70 \mathrm{~mm}$ range.

\section{Panel net and experiment setup}

For the purpose of this study panel nets with 21 pockets were used (Figure 1). After the spats were chosen, they were cleaned using a hand brush and placed into panel nets. Twenty one oysters were placed in each panel net. There were 4 treatments with 5 replicates. A total of 105 spats were subjected to each treatment. The treatments were as follows:

- $\mathbf{1}^{\text {st }}$ treatment: The spats were cleaned every 2 weeks.

- $2^{\text {nd }}$ treatment: The spats were cleaned every 4 weeks.

- $3^{\text {rd }}$ treatment: The spats were cleaned every 6 weeks.

- $4^{\text {th }}$ treatment: The spats were cleaned after 20 weeks of the experiment.

The panel nets were placed on the longline, adjacent to each other (Figure 2).

*Corresponding author: Ram EJ, School of Marine Studies, University of the South Pacific, Suva, Republic of Fiji, Tel: +679 338 1044; E-mail: ram_emanuel@yahoo.com

Received June 04, 2018; Accepted July 15, 2018; Published July 20, 2018

Citation: Ram EJ, Morris C (2018) Cleaning Regime for Pinctada margaritifera (Linneaus, 1758) in Savusavu Bay, Fiji. J Aquac Res Development 9: 542. doi: 10.4172/2155-9546.1000542

Copyright: @ 2018 Ram EJ, et al. This is an open-access article distributed under the terms of the Creative Commons Attribution License, which permits unrestricted use, distribution, and reproduction in any medium, provided the original author and source are credited. 


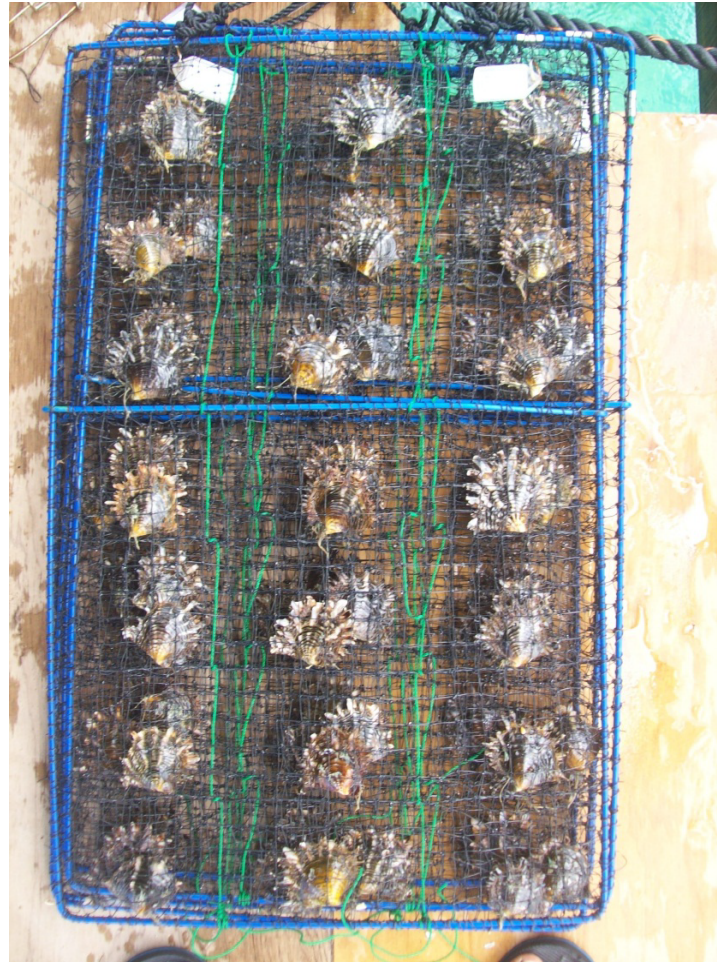

Figure 1: $P$. margaritifera spat in 21 pocket panels net at the Valili pearl farm.

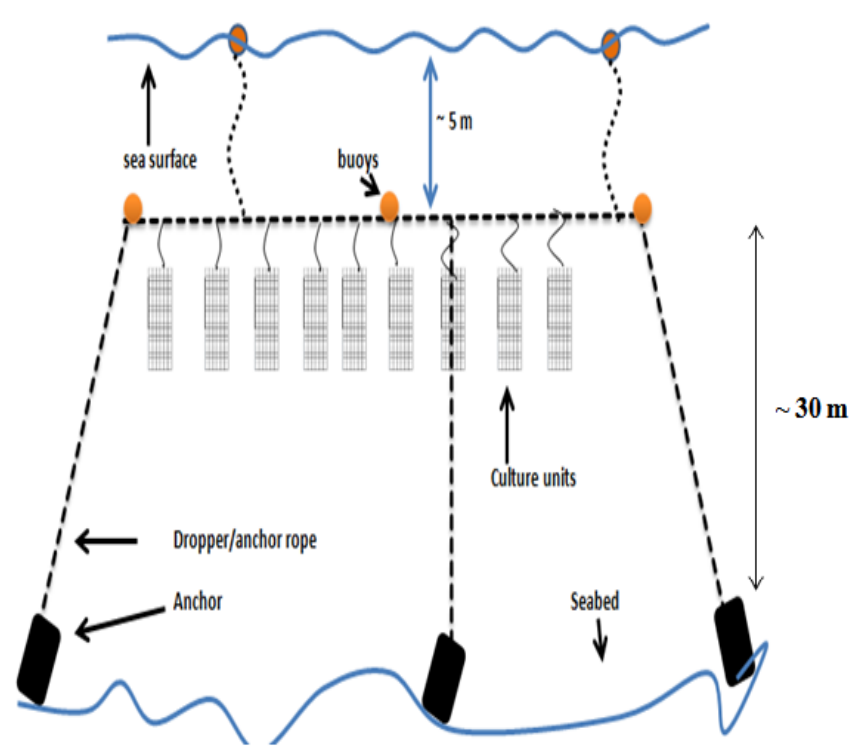

Figure 2: Subsurface longline culture method used for the experiment at Valil pearl farm

\section{Growth measurements}

Measurements were taken from the center of the hinge at a $90^{\circ}$ angle to the hinge line across to the shell margin (DVM or DVH) by Nicholls in 1931, (Figure 3). A Vernier calliper was used for measurements which were recorded at 2 decimal points.

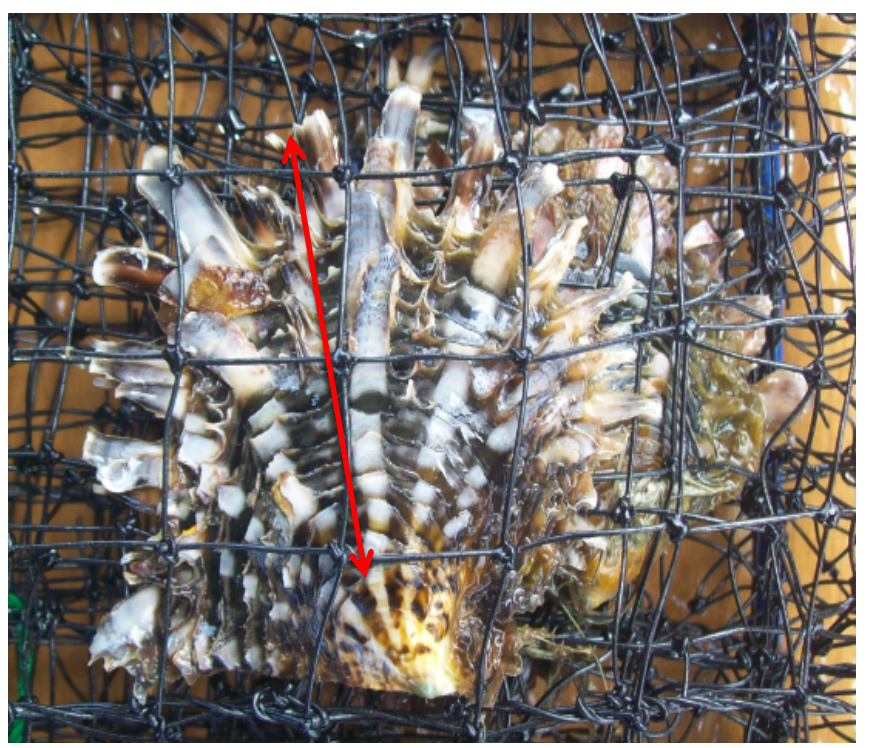

Figure 3: A P. margaritifera spat in a panel net at the Valili pearl farm with the dorso-ventral measurement (DVM) shown by the red arrow.

\section{Cleaning and redeployment}

During the cleaning the panel nets were retrieved from the sea and brought to the seeding house (Figure 1). At the seeding house the spat were carefully removed from the panel nets by cutting of the byssal (thread secreted by the oyster and used for attachment) using a kitchen knife. The principal investigator with the help of an Assistant would then clean the spats by removing the biofouling organisms using a scrubbing brush and a kitchen chopper. Soft biofoulers, such as polycheates, gastropods, ascidians, algae, caprilids, amphipods, byozoans, were removed using scrubbing brush while the hard biofouling organisms, such as barnacles, encrusting sponges and other bivalves, were removed using the chopper. This method of cleaning is generally practiced by local pearl farmers. The cleaned spats were then measured for its DVM using a caliper. After measurements, the spats were placed into a new set of panel nets and deployed back into the sea on the longlines where they were initially suspended. The used panel nets were cleaned and placed into sun to kill the remaining biofouling organisms. These panel nets were used for the next round on rotational basis (Figure 4).

\section{Water parameters}

The water parameters were measured using YSI 6920 data logger. YSI 6920 was programmed and left suspended at the experiment site where it recorded water parameters such as salinity, depth, temperature and $\mathrm{pH}$. Data was retrieved from the equipment during sampling.

\section{Recording and analysis}

The raw data of the four cleaning regimes of were tested for normality using Shapiro-Wilk test [13] and homogeneity of variance using Levene's test [14]. Data was then analysed using one-way ANOVA to examine the variability in growth of the four cleaning regimes over time. Tukey's HSD test was used to find means that were significantly different from each other. The entire tests were performed using SPSS version 22 statistical package. 
Citation: Ram EJ, Morris C (2018) Cleaning Regime for Pinctada margaritifera (Linneaus, 1758) in Savusavu Bay, Fiji. J Aquac Res Development 9: 542. doi: $10.4172 / 2155-9546.1000542$

\section{Results}

\section{Growth of pearl oysters}

There was a gradual increase in growth of oysters for all four treatments. MOP oysters treated with the 6 week cleaning regime showed the highest mean growth of $11.01 \pm 0.5 \mathrm{~mm}$. Oysters exposed to the 4 week cleaning regime displayed the second highest mean growth of $10.85 \pm 0.5 \mathrm{~mm}$ followed by oysters that were cleaned on a 2 week basis with $9.72 \pm 0.5 \mathrm{~mm}$ mean growth. The oysters that were cleaned after 20 weeks attained the lowest mean growth of $9.46 \pm 0.5$ $\mathrm{mm}$. Survival of oysters was $100 \%$ for the 6 and 4-week treatments, $98 \%$ for the 2 week treatment and $99 \%$ for the 20 week treatment (Table 1 and Figures 5-10).

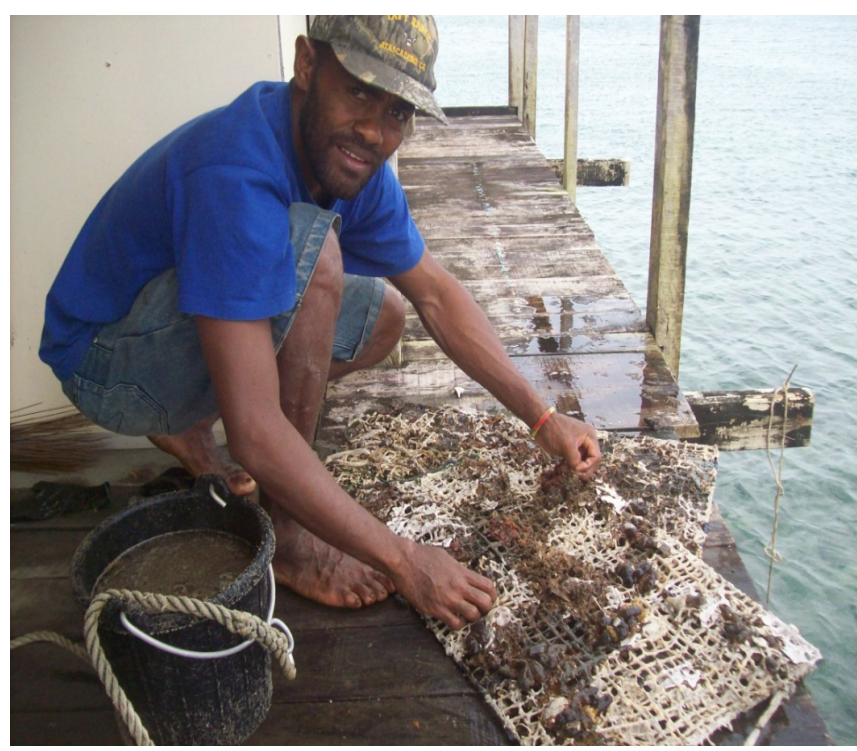

Figure 4: Napolioni removing P. margaritifera oysters from the panel net.

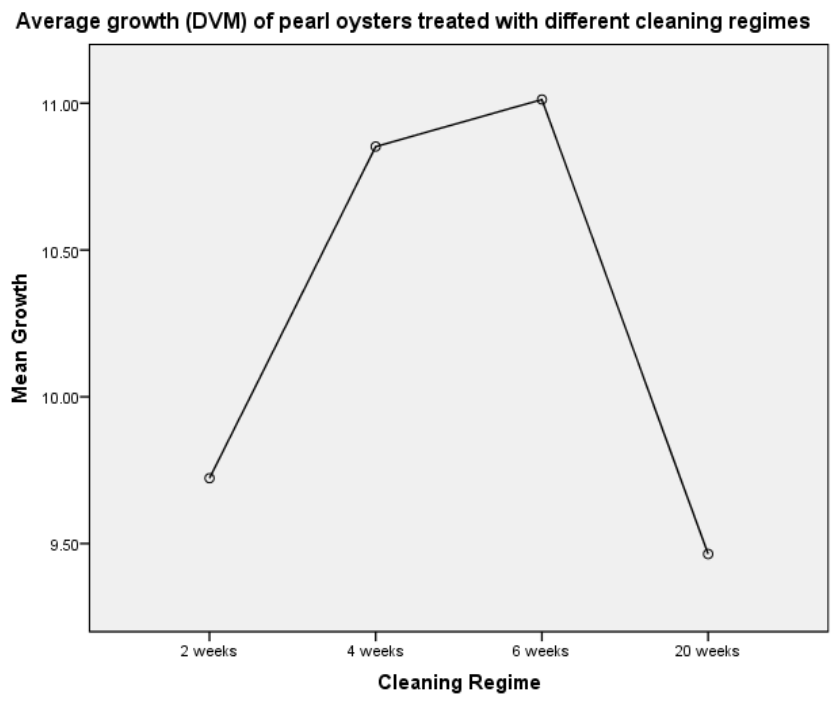

Figure 5: Average growth of $P$. margaritifera mother of pearl oysters treated with different cleaning regimes in Savusavu bay from January 2012 through to June 2012.

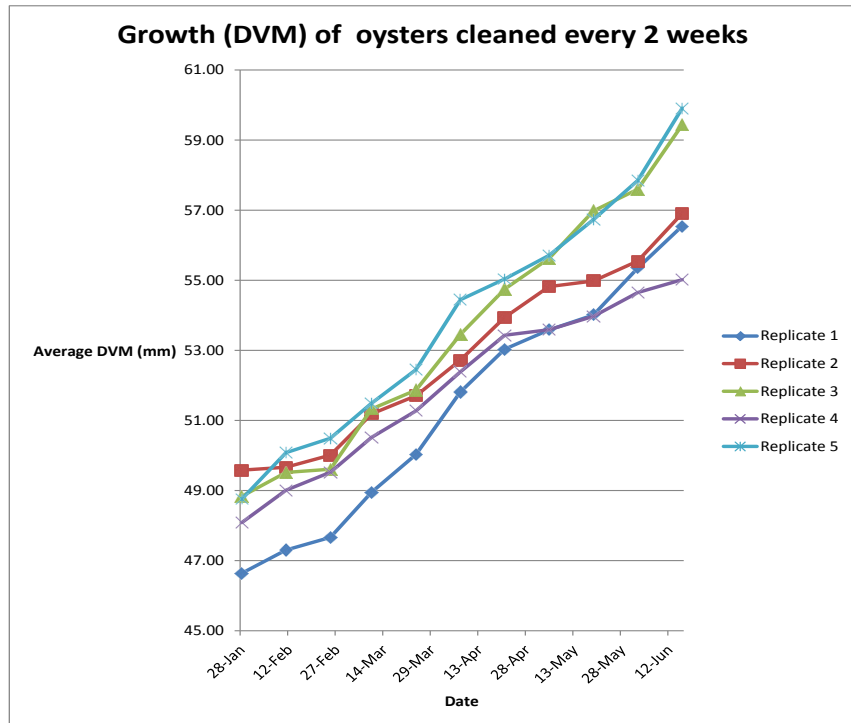

Figure 6: Time series for the 2 weeks cleaning regime of $P$. margaritifera mothe of pearl oysters in Savusavu Bay from January 2012 through to June 2012.

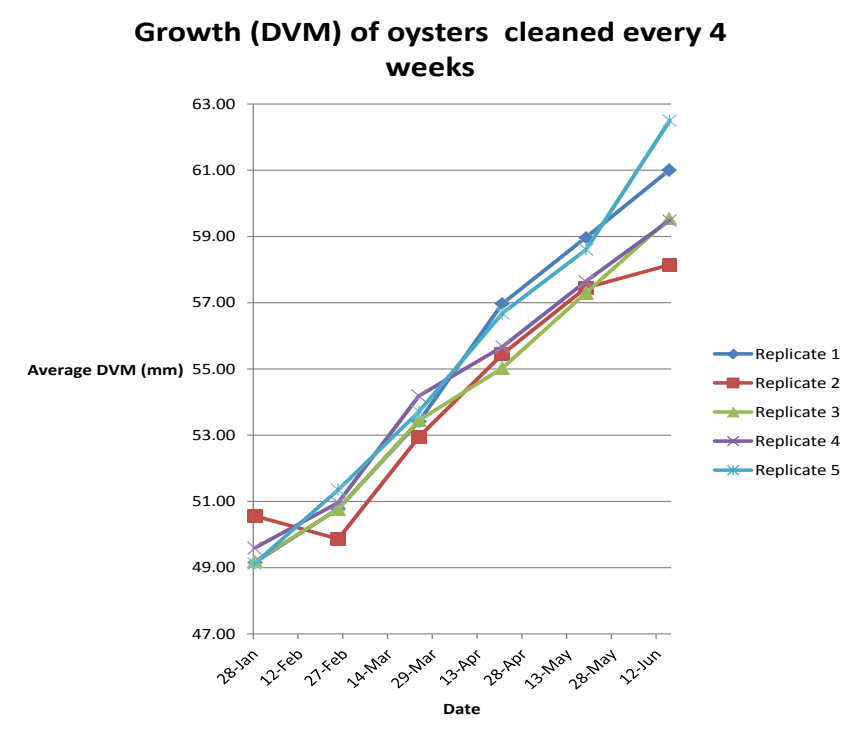

Figure 7: Time series for the 4 weeks cleaning regime of $P$. margaritifera mother of pearl oysters in Savusavu Bay from January 2012 through to June 2012.

The normality test showed that growth data for cleaning regime (2 week, 4 week, 6 week and 20 week) settlement was normally distributed hence a non-parametric test was run. There was a statistically significant difference between treatments as determined by one-way ANOVA ( $\mathrm{F}$ $(3,413)=6.433, p=0.0003)$. Post hoc Tukey's test showed that the oysters cleaned at the 4 and 6 week cleaning regimes had significantly higher growth than those that were cleaned at the 2 and 20 week cleaning regimes. Hence there was a significant difference between the growth of oysters treated with 4 different cleaning regimes in Savusavu bay between the months of January, 2012 and June, 2012.

The temperature varied within $25^{\circ} \mathrm{C}$ to $30^{\circ} \mathrm{C}$ throughout the experiment period. The salinity stayed above $30 \mathrm{ppt}$ but did not exceed $35 \mathrm{ppt}$. The $\mathrm{pH}$ ranged from 7 to 8 while the depth of longline was kept approximately 6 meters below water surface. 
Citation: Ram EJ, Morris C (2018) Cleaning Regime for Pinctada margaritifera (Linneaus, 1758) in Savusavu Bay, Fiji. J Aquac Res Development 9: 542. doi: $10.4172 / 2155-9546.1000542$

Page 4 of 5

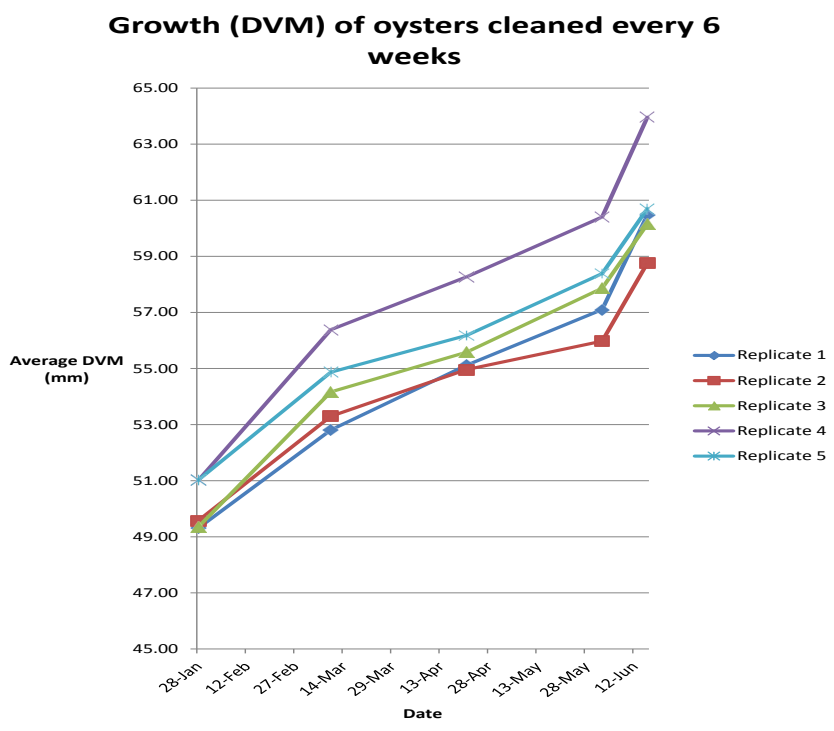

Figure 8: Time series for the 6 weeks cleaning regime of $P$. margaritifera mothe of pearl oysters in Savusavu Bay from January 2012 through to June 2012.

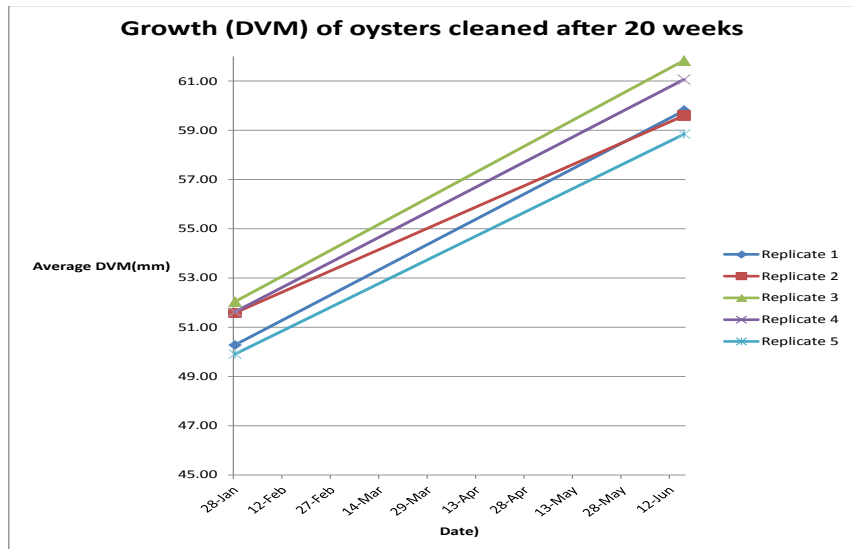

Figure 9: Time series for the 20 weeks cleaning regime of $P$. margaritifera mother of pearl oysters in Savusavu Bay from January 2012 through to June 2012.

\section{Discussion}

For the current study it was observed that MOP oysters had better growth when they were cleaned every 4 and 6 weeks (Figure 5) compared to oysters that were cleaned every 2 and 20 weeks. Similary Mohammad reported an inverse relationship between $P$. fucata growth and increasing diversity of biofoulers. In contrast, in Australia $P$. maxima oysters had the highest growth when they were cleaned every 2 to 4 weeks compared to oysters that were cleaned after 8 and 16 weeks. From this study, it was recommended that oysters be cleaned on a monthly basis [15].

Pit and Southgate [16] found that oysters which weren't cleaned for 16 weeks had the lowest DVH. However, they found that oysters cleaned every 4 and 8 weeks had no significant difference in DVH. In addition, survival was lowest for oysters cleaned every 4 weeks and no differences were found with oysters cleaned every 8 weeks and those not cleaned for 16 weeks.

The frequency and intensity of cleaning regime can have a

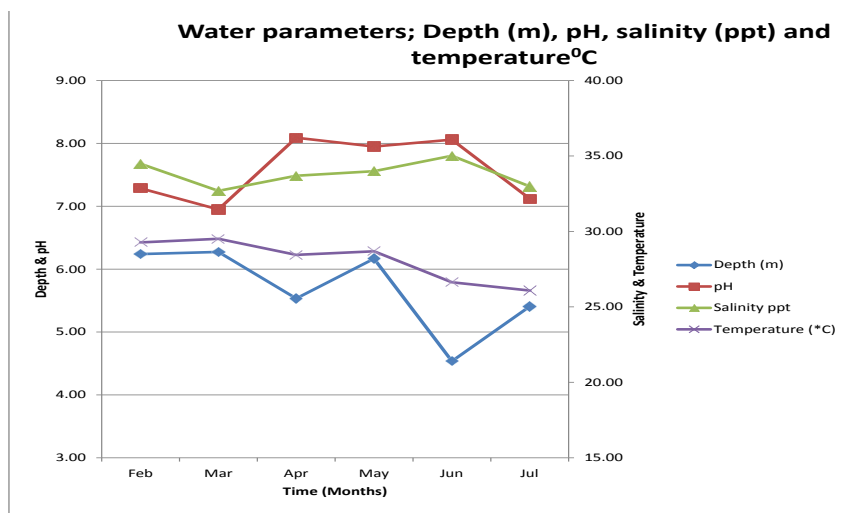

Figure 10: Average monthly water quality parameters (Depth, $\mathrm{pH}$, salinity, temperature) retrieved from the YSI 6920 data logger placed at the experiment site in Savusavu Bay, Fiji.

\begin{tabular}{|c|c|}
\hline Frequency of cleaning & DVM $(\mathbf{m m})$ \\
\hline 2 weeks & $9.72 \pm 0.5$ \\
\hline 4 weeks & $10.85 \pm 0.5$ \\
\hline 6 weeks & $11.01 \pm 0.5$ \\
\hline 20 weeks & $9.46 \pm 0.5$ \\
\hline
\end{tabular}

Table 1: Final means ( \pm S.E.) dorso-ventral measurement (DVM) for $P$ margaritifera from which fouling organisms were removed every 2,4 , and 6 weeks and after 20 weeks.

substantial consequence on MOP oyster growth. Frequent cleaning requires handling of oysters out of water and changing of nets [15]. More frequent cleaning and panel net changing possibly increases the chances of damage to oysters. The oysters feeding regime is also disturbed when removed from water, which may possibly hinder the overall growth of oysters [17]. For the present study the oysters were kept out of water for maximum of five minutes otherwise they were kept submerged in water. To reduce the effect of cleaning on oysters and production cost, frequency of cleaning needs to be minimized but not to that extent that biofouling starts affecting the oyster growth [18]. Currently on the Valili Pearl Farm, the practice is to clean pearl oysters whenever possible without any standard or fixed regime.

Handling in the current study seemed to have little effect on the oysters' survival. Mortalities were low in general and were not very different between treatments. Most frequently handled oysters such as those which were cleaned every 2 weeks, had two mortalities while the oysters that were cleaned every 4 week and 6 weeks had zero mortality. According to Pit et al. [16] growth and survival of oysters is negatively affected by fouling and cleaning. Manually cleaning of the fouling organisms requires a considerable amount of handling, which in some cases can be detrimental to cultured oysters. A good example of this was seen in a study where frequent handling of giant scallop resulted in 23\% mortality of Placopecten magellanicus [19]. In contrast increased handling had a positive effect on the survival and growth rate of Crassostrea gigas spats [20].

The major water parameters, salinity and temperature (Figure 7) indicated that the oysters were near to optimum temperature and salinity ranges. Optimum functioning temperature for species is $26^{\circ} \mathrm{C}$ to $29^{\circ} \mathrm{C}$ [21]. Marine oysters can tolerate wide salinity ranges from $40-$ $50 \mathrm{ppt}$ [22]. However, the optimum salinity range for is $28-30 \mathrm{ppt}$ [21].

Regular cleaning is necessary to get rid of unwanted fouling organisms. It has been observed in Indonesia and Australia, that 
Citation: Ram EJ, Morris C (2018) Cleaning Regime for Pinctada margaritifera (Linneaus, 1758) in Savusavu Bay, Fiji. J Aquac Res Development 9: 542. doi: $10.4172 / 2155-9546.1000542$

Page 5 of 5

regular cleaning encouraged healthy growth of $P$. maxima oysters [15]. Frequent cleaning without substantial growth of oysters unnecessarily increases production costs. A study in Australia reported that the cost of removal of fouling was $30 \%$ of the total operational cost of bivalve farming [23]. Taylor et al. [15], suggested that to maximize cleaning and keep costs low, farmers need to know the nature of the water quality and fouling organisms at their farm site and avoid deploying oyster spats during heavy fouling periods.

\section{Conclusion}

Under the environment conditions experienced during the current study and the same method of cleaning, MOP oysters had varied growth when they were subjected to different cleaning frequencies. This study showed that for the best survival and growth of MOP oysters in Savusavu Bay should be treated with a 4 to 6 week cleaning regime.

\section{References}

1. Kishore P (2010) Potential for Pteria penguin (Roding, 1798) Mabe Pearl Aquaculture by Rural Coastal Communities in the Fiji Islands. M.Sc. thesis. The University of the South Pacific, Suva.

2. Rose J, Baker P (1994) The pearl oyster. Lucas J (Ed) Paul Southgate, Elsevier, The Netherlands.

3. Southgate PC (2008) Pearl oyster culture. P. C. Southgate, Elsevier, Oxford, UK. 527-553.

4. Stephane P, Vincent $P$ (2001) Growth of the black-lip pearl oyster, Pinctada margaritifera, at nine culture sites of French Polynesia: The synthesis of several sampling designs conducted between 1994 and 1999. Aqu Liv Res 14: 155-163.

5. O'Connor WA, Lawler N (2003) Trial farming the akoya pearl oyster, Pinctada imbricata, in Port Stephens. NSW. Final Report to Australian Radiata Pty Ltd. NSW Fisheries Final Report Series p: 175

6. Taylor JJ, Strack E (2008) Pearl production. In: Southgate, C. P. and Lucas, S J. (Eds) The Pearl Oyster. Elsevier, Amsterdam. pp: 273-302.

7. Yukihira H, Klumpp D, Lucas J (1999) Feeding adaptations of the pearl oysters Pinctada margaritifera and $P$. maxima to variations in natural particulates. Marine Ecology Progress Series 182:163-173.

8. Alexander KL, Entwisle DR, Bedinger SD (1994) When expectations work: Race and socioeconomic differences in school performance. Soc Psychol Q 57: 283-299.

9. Pilditch CA, Grant J (1999) Effect of temperature fluctuations and food supply on the growth and metabolism of juvenile sea scallops (Placopecten magellanicus). Marine Biol 134: 235-248.

10. Tettelbach ST, Rhodes EW (1981) Combined affects of temperature and salinity on embryos and larvae of the northern bay scallop Argopecten irradians irradians. Marine Biol 63: 249-256.

11. Lodeiros CJM, Himmelman JH (1996) Influence of fouling on the growth and survival of the tropical scallop, Euvola (Pecten) ziczac (L. 1758) in suspended culture. Aquacult Res 27: 749-756.

12. Smitasiri D (1994) Culture, Environment and Food to Prevent Vitamin A Deficiency. Harriet V. Kuhnlein, Gretel H. Pelto, (Eds) International Development Research Centre: International Nutrition Foundation for Developing Countries, Canada.

13. Shapiro SS, Wilk MB (1965)An analysis of variance test for normality (Complete samples). Biometrika Trust 52: 591-611.

14. https://www.itl.nist.gov/div898/handbook/eda/section3/eda35a.htm

15. Taylor JJ, Southgate PC, Rose RA (1997) Fouling animals and their effect on the growth of silverlip pearl oysters, Pinctada maxima (Jameson) in suspended culture. Aquaculture 153: 31-40.

16. Pit JH, Southgate PC (2003) Fouling and predation: How do they affect growth and survival of the blacklip pearl oyster, Pinctada margaritifera, during nursery culture? Aquac Int 11: 545- 555

17. Fitridge IT, Dempster J, Guenther RD (2012) The impact and control of biofouling in marine aquaculture: A review. J Bioadhesion and Biofilm Res 28 . 649-669.

18. Guenther J, Southgate PC, De NR (2006) The effect of age and shell size on accumulation of fouling organisms on the Akoya pearl oyster Pinctada fucata (Gould). Aquacult 253: 366-373.

19. Parsons GJ, Dadswell MJ (1992) Effect of stocking density on growth production and survival of the giant scallop, Placopecten magellanicus, held in intermediate suspension culture in Passamaquoddy Bay, New Brunswick. Aquaculture 103: 291-309.

20. Jakob GS, Wang J (1994) The effect of manual handling on oyster growth in land-based cultivation. J Shellfish Res 13: 183-186.

21. Doroudi MS, Southgate PC, Mayer RJ (1999) The combined effects of temperature and salinity on embryos and larvae of the blacklip pearl oyster Pinctada margaritifera. Aquacult Res 30: 271-277.

22. Al-Sayed H, El-Din AKG, Salesh KM (1997) Shell morphometric and some biochemical aspects of the pearl oyster Pinctada radiata (Leach, 1814) in relation to different salinity levels around Bahrain. Arab Gulf J Sci Res 15: 767-782.

23. Claereboudt MR, Bureau D, Cote J, Himmelman JH (1994) Fouling development and its effect on the growth of juvenile giant scallops (Placopecten magellanicus) in suspended culture. Aquaculture 121: 327-342. 